Sādhanā Vol. 38, Part 6, December 2013, pp. 1433-1450. (C) Indian Academy of Sciences

\title{
Role of friction stir processing parameters on microstructure and microhardness of boron carbide particulate reinforced copper surface composites
}

\author{
R SATHISKUMAR $^{1, *}, \mathrm{~N}_{\text {MURUGAN }}^{1}$, \\ I DINAHARAN $^{2}$ and $S$ J VIJAY ${ }^{3}$ \\ ${ }^{1}$ Department of Mechanical Engineering, Coimbatore Institute of Technology, \\ Coimbatore 641 014, India \\ ${ }^{2}$ Department of Mechanical Engineering, V V College of Engineering, \\ Tisaiyanvilai 627 657, India \\ ${ }^{3}$ School of Mechanical Sciences, Karunya University, Coimbatore 641 114, India \\ e-mail: sathiscit2011@gmail.com; sathismh@gmail.com; murugan@cit.edu.in; \\ dinaweld2009@gmail.com; vijayjoseph.2001@gmail.com
}

MS received 10 October 2012; revised 26 March 2013; accepted 24 May 2013

\begin{abstract}
Friction stir processing (FSP) was applied to fabricate boron carbide $\left(\mathrm{B}_{4} \mathrm{C}\right)$ particulate reinforced copper surface composites. The effect of FSP parameters such as tool rotational speed, processing speed and groove width on microstructure and microhardness was investigated. A groove was contrived on the $6 \mathrm{~mm}$ thick copper plates and packed with $\mathrm{B}_{4} \mathrm{C}$ particles. FSP was carried out using five various tool rotational speeds, processing speeds and groove widths. Optical and scanning electron microscopies were employed to study the microstructure of the fabricated surface composites. The results indicated that the selected FSP parameters significantly influenced the area of surface composite, distribution of $\mathrm{B}_{4} \mathrm{C}$ particles and microhardness of the surface composites. Higher tool rotational speed and lower processing speed produced an excellent distribution of $\mathrm{B}_{4} \mathrm{C}$ particles and higher area of surface composite due to higher frictional heat, increased stirring and material tranportation. The $\mathrm{B}_{4} \mathrm{C}$ particles were bonded well to the copper matrix and refined the grains of copper due to the pinning effect of $\mathrm{B}_{4} \mathrm{C}$ particles. $\mathrm{B}_{4} \mathrm{C}$ particles retained the original size and morphology because of its small size and minimum sharp corners in the morphology.
\end{abstract}

Keywords. Surface composites; friction stir processing; copper; $\mathrm{B}_{4} \mathrm{C}$.

\section{Introduction}

Copper-based ceramic particulate reinforced metal matrix composites (CMMCs) have been gaining much attention owing to their good mechanical, thermal and tribological properties. CMMCs

*For correspondence 
are applied where good wear resistance without loss of thermal and electrical conductivity of the matrix is needed (Dhokey \& Paretkar 2008). The introduction of hard, non-deformable ceramic particles into matrix alloy causes a loss in ductility and toughness of CMMC. The life of components depends on surface properties in many applications. Therefore, it is appropriate to modify the surface of the component by reinforcing with ceramic particles while the inner matrix retains the ductility and toughness. The modified surface layer is called as surface composite (Attia 2001).

Friction stir processing (FSP) is a novel solid state technique to fabricate surface composite. Mishra et al (2003) developed FSP, based on the principles of friction stir welding (FSW). One method to produce surface composite using FSP is to make a groove of required depth, compact with ceramic particles, plunge the tool and traverse along the groove (Yadav \& Bauri 2010). The frictional heat softens the matrix alloy and the ceramic particles are distributed within the plasticized matrix alloy by the stirring action of the tool. This technique has been effectively explored by several investigators to fabricate surface composite on aluminum, magnesium, steel and titanium alloys (Mazaheri et al 2011; Mahmoud et al 2008; Asadi et al 2010, 2011; Salekrostam et al 2010; Shamsipura et al 2011).

Barmouz et al (2011a, b, c) successfully applied the FSP technique to fabricate $\mathrm{Cu} / \mathrm{SiC}$ surface composite in recent times. They have studied various aspects of the FSP process on the formation of $\mathrm{Cu} / \mathrm{SiC}$ surface composite. It was reported that the processing speed significantly influenced the distribution of $\mathrm{SiC}$ particles. Higher processing speed led to poor distribution of $\mathrm{SiC}$ particles and vice versa (Barmouz et al 2011a). The size of the $\mathrm{SiC}$ particles considerably influenced the grain size and wear rate of $\mathrm{Cu} / \mathrm{SiC}$ surface composite. Nano size SiC particles yielded finer grains and lower wear rate compared to macro size $\mathrm{SiC}$ particles. Increased volume fraction of both micro and nano sized $\mathrm{SiC}$ particles enhanced the wear resistance of the composite layer (Barmouz et al 2011b). Increasing the number of passes resulted in the reduction of the $\mathrm{SiC}$ particles size and grain size of copper and improved the dispersion and separation of SiC particles due to longer processing time and severe stirring action in the stir zone (Barmouz \& Givi 2011). The tool pin profile also contributed to the formation of $\mathrm{Cu} / \mathrm{SiC}$ surface composite. A straight cylindrical pin profile produced a uniform distribution of $\mathrm{SiC}$ particles and finer grain size in the stir zone, increased hardness and wear resistance compared to the square pin profile (Barmouz et al 2011c).

The major process parameters which influence the microstructure and other properties of surface composite are tool rotational speed, processing speed, axial force, tool pin profile, number of passes and groove design. Some studies on the effect of those process parameters on the surface composites fabricated on aluminum and magnesium alloys were reported in the literature. Mahmoud et al (2008) fabricated AA1050/SiC surface composite using FSP and reported that higher tool rotational speed and multiple pass improved the dispersion of SiC particles. Mahmoud et al (2009) investigated the effect of tool pin profile on the microstructure of AA1050/SiC surface composite and concluded that square tool pin profile yielded finer distribution of $\mathrm{SiC}$ particles. Yang et al (2010) synthesized AA6061/ $\mathrm{Al}_{2} \mathrm{O}_{3}$ nano surface composite using FSP and observed homogeneous distribution of nano $\mathrm{Al}_{2} \mathrm{O}_{3}$ particles when axial force and the number of passes were increased. Asadi et al (2010) developed AZ91/SiC surface composite using FSP and analysed the effect of tool rotational speed, processing speed and tool tilt angle on the formation of macroscopic defects. Azizieh et al (2011) produced $\mathrm{AZ31} / \mathrm{Al}_{2} \mathrm{O}_{3}$ nano surface composite using FSP and noticed uniform distribution of $\mathrm{Al}_{2} \mathrm{O}_{3}$ particles at higher tool rotational speed using threaded profile tool after four passes.

Boron carbide $\left(\mathrm{B}_{4} \mathrm{C}\right)$ has excellent chemical and thermal stability, high hardness and low density and is used for manufacturing of armor tank, neutron shielding material, etc. (Chen et al 
2009; Guo et al 2011, 2012). $\mathrm{B}_{4} \mathrm{C}$ coating is applied on copper and steel using various methods which is extensively used in nuclear industries (Nanobashvili et al 2002; Maruyama \& Onose 1999). In the present work, an attempt is made to fabricate $\mathrm{Cu} / \mathrm{B}_{4} \mathrm{C}$ surface composite using FSP and study the effect of tool rotational speed, processing speed and groove width on the microstructure and microhardness of the same.

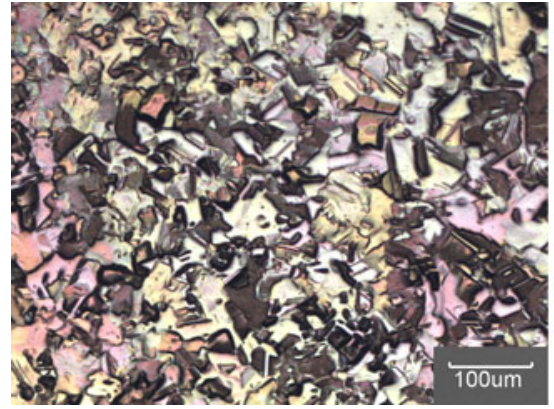

(a)

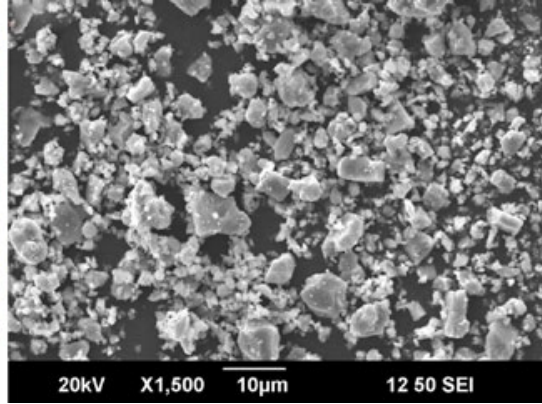

(b)

Figure 1. (a) Optical photomicrograph of copper and (b) SEM micrograph of $\mathrm{B}_{4} \mathrm{C}$ particles.

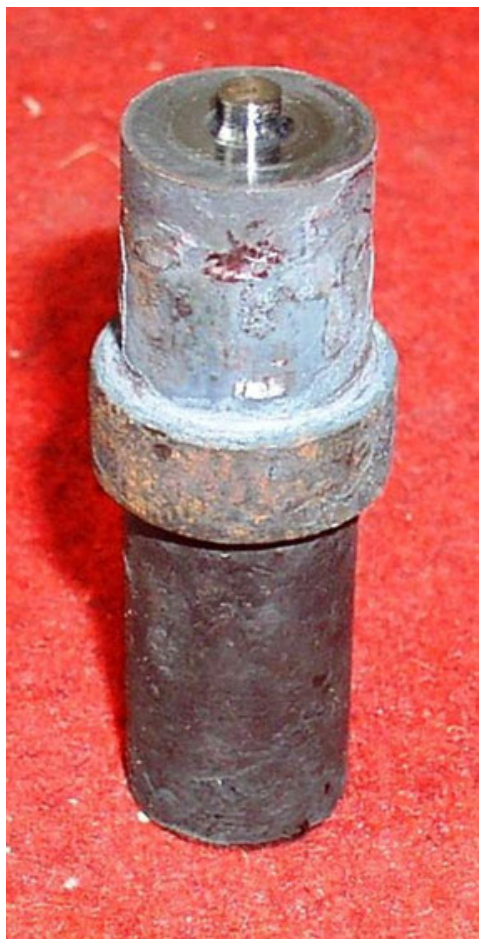

Figure 2. Fabricated friction stir processing tool. 
Table 1. Friction stir processing plan.

\begin{tabular}{ll}
\hline Process parameters & Values \\
\hline Tool rotational speed $(\mathrm{rpm})$ & $800,900,1000,1100$ and 1200 \\
Processing speed $(\mathrm{mm} / \mathrm{min})$ & $20,30,40,50$ and 60 \\
Axial force $(\mathrm{kN})$ & 10 \\
Tool tilt angle $\left(^{\circ}\right)$ & 0 \\
Tool shoulder diameter $(\mathrm{mm})$ & 20 \\
Tool shoulder surface & Flat \\
Pin diameter $(\mathrm{mm})$ & 5 \\
Pin length $(\mathrm{mm})$ & 3 \\
Pin profile & Straight cylindrical \\
Groove width $(\mathrm{mm})$ & $0,0.35,0.70,1.05$ and 1.40 \\
Groove depth $(\mathrm{mm})$ & 2.5 \\
Groove length $(\mathrm{mm})$ & 100 \\
\hline
\end{tabular}

\section{Experimental procedure}

Commercially available pure copper plates of $100 \mathrm{~mm}$ length, $50 \mathrm{~mm}$ width and $6 \mathrm{~mm}$ thickness were used in this study. The optical photomicrograph of as received copper plate is shown in figure 1a. A groove was made in the middle of the plate using wire EDM and compacted with $\mathrm{B}_{4} \mathrm{C}$ powder. The average size of $\mathrm{B}_{4} \mathrm{C}$ particles is $4 \mu \mathrm{m}$. The SEM photomicrograph of $\mathrm{B}_{4} \mathrm{C}$ particles is shown in figure $1 \mathrm{~b}$. A pinless tool was initially employed to cover the top of the groove after filling with $\mathrm{B}_{4} \mathrm{C}$ particles to prevent the particles from scattering during FSP. A tool made of double tempered hot working steel as shown in figure 2 was used in this study. The tool had a shoulder diameter of $20 \mathrm{~mm}$, pin diameter of $5 \mathrm{~mm}$ and pin length of $3 \mathrm{~mm}$. The FSP was

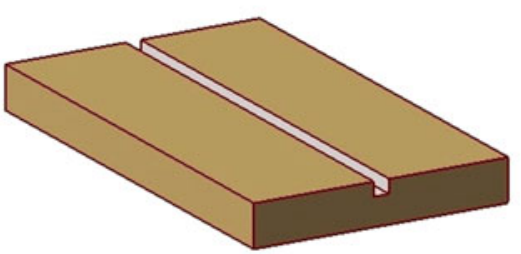

(a)

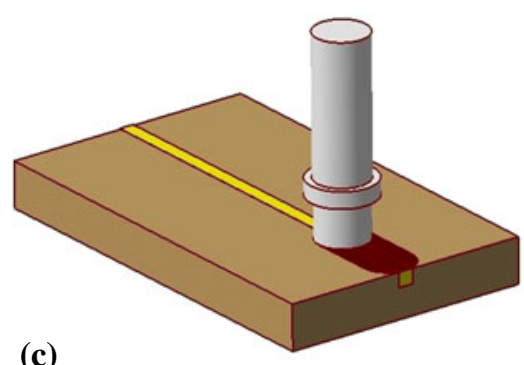

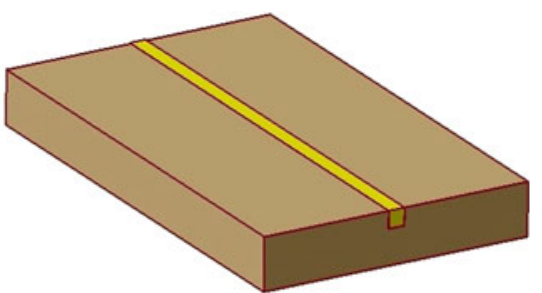

(b)

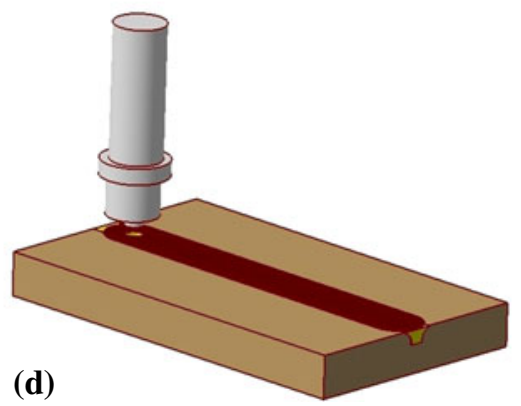

Figure 3. FSP procedure to fabricate surface composite: (a) cutting a groove, (b) compacting the groove with ceramic particles, (c) processing using a pinless tool and (d) processing using a tool with pin. 
carried out on an indigenously built FSW machine as per the processing plan given in table 1 . The FSP procedure to produce surface composite is schematically shown in figure 3.

Two specimens were obtained from the centre of the friction stir processed plate and were polished as per standard metallographic procedure. The polished specimens were etched with a colour etchant containing $20 \mathrm{~g}$ chromic acid, $2 \mathrm{~g}$ sodium sulphate, $1.7 \mathrm{ml} \mathrm{HCl}(35 \%)$ in $100 \mathrm{ml}$ distilled water. The digital image of the macrostructure of the etched specimen was captured using a digital optical scanner. The microstructure was observed using a metallurgical microscope and a scanning electron microscope. The microhardness was measured using a microhardness tester at $500 \mathrm{~g}$ load applied for $15 \mathrm{~s}$ at various locations in the surface composite.

\section{Results and discussions}

The typical crown appearance of friction stir processed copper with $\mathrm{B}_{4} \mathrm{C}$ particles is shown in figure 4 . The crown presents a smooth appearance without depressions or prominences. Semicircular features similar to those formed during the conventional milling process are seen. The selected process parameters are sufficient to produce defect-free crown. The process parameters were selected based on trial experiments. Some of the defects encountered in trail experiments such as rough surface induced by insufficient plastic flow, tool dragging, incomplete bonding and cracks are displayed in figure 5. It is essential to obtain a smooth crown appearance owing to the fact that each surface irregularity in the crown leads to other kind of internal defects in the surface composite.

\subsection{Effect of tool rotational speed}

The variation of macrostructure when tool rotational speed was increased from $800 \mathrm{rpm}$ to $1200 \mathrm{rpm}$ is presented in figure 6 . The processing speed $(40 \mathrm{~mm} / \mathrm{min})$ and groove width $(0.7 \mathrm{~mm})$ were kept constant. It is evident from the figure and table 2 that the tool rotational speed greatly influences the area of friction stir processed zone which contains the surface composite. When tool rotational speed was increased, the area of surface composite increased. The area of surface composite was measured using an image analysing software. The area of surface composite was found to be $27 \mathrm{~mm}^{2}$ at $800 \mathrm{rpm}$ and $39 \mathrm{~mm}^{2}$ at $1200 \mathrm{rpm}$.

The rubbing of the tool shoulder on the copper substrate generates frictional heat. The amount of frictional heat generated is dependent on the tool rotational speed (Rajakumar et al 2011). The frictional heat causes the copper to plasticize. The amount plasticized copper is dependent on the available frictional heat. When the tool rotational speed increases, the frictional heat generated

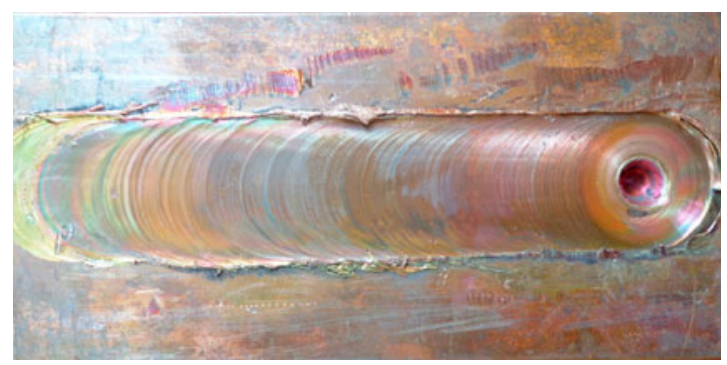

Figure 4. Typical crown appearance of friction stir processed copper using $\mathrm{B}_{4} \mathrm{C}$ particles. 


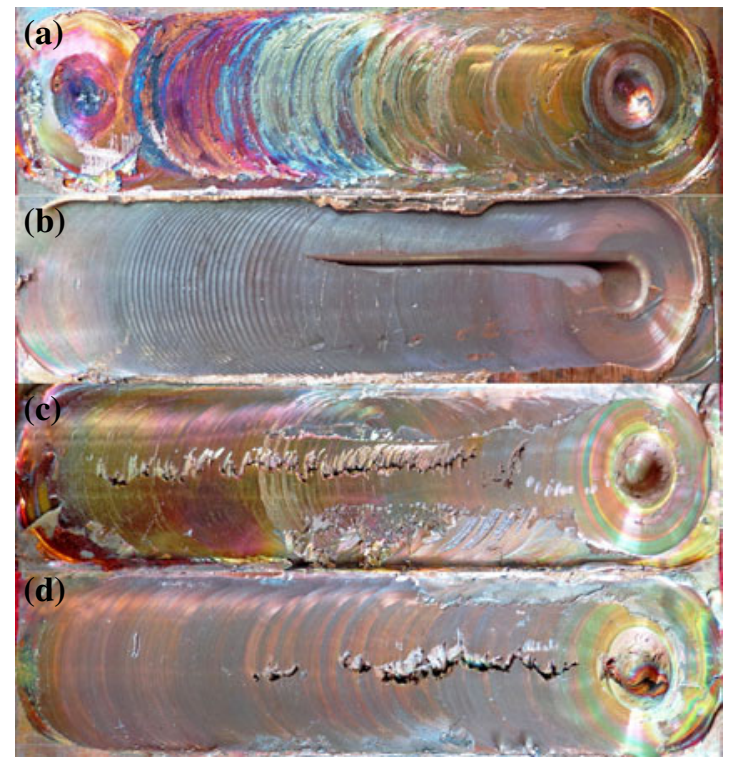

Figure 5. Typical defects appeared in trial specimens: (a) rough surface induced by insufficient plastic flow, (b) tool dragging, (c) incomplete bonding and (d) cracks.

increases. The amount of plasticized copper is subsequently increased. Therefore, the area of surface composite increases when tool rotational speed is increased.

The effect of tool rotational speed on the microstructure of $\mathrm{Cu} / \mathrm{B}_{4} \mathrm{C}$ surface composite is shown in figure 7 . The optical micrographs clearly reveal the distribution of $\mathrm{B}_{4} \mathrm{C}$ particles in the copper matrix. The distribution is not uniform at $800 \mathrm{rpm}$ due to the presence of agglomeration

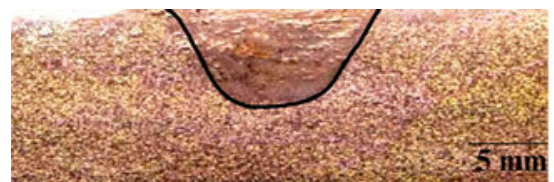

(a)
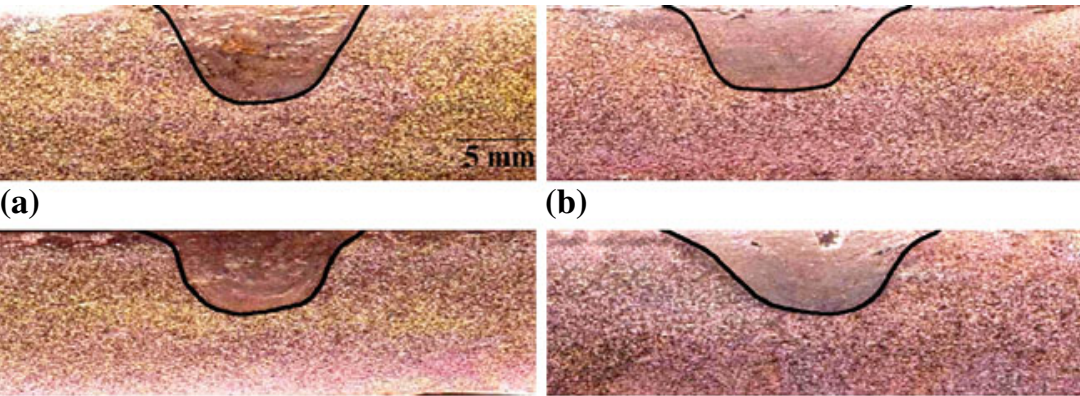

(b)

(c)

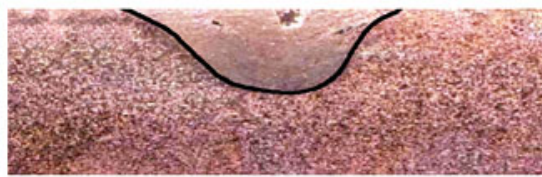

(d)

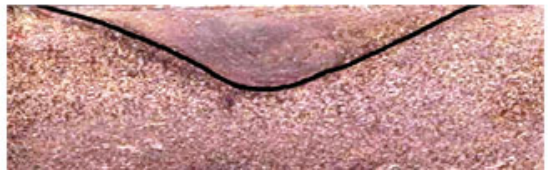

(e)

Figure 6. Macrostructure of friction stir zone at tool rotational speed: (a) $800 \mathrm{rpm}$, (b) $900 \mathrm{rpm}$, (c) $1000 \mathrm{rpm}$, (d) $1100 \mathrm{rpm}$ and (e) $1200 \mathrm{rpm}$. 
Table 2. Effect of FSP parameters on the properties of copper surface composite.

\begin{tabular}{|c|c|c|c|c|c|}
\hline FSP parameter & Value & $\begin{array}{l}\text { Area of the surface } \\
\text { composite }\left(\mathrm{mm}^{2}\right)\end{array}$ & $\begin{array}{l}\text { Average grain } \\
\text { size }(\mu \mathrm{m})\end{array}$ & $\begin{array}{l}\text { Theoretical volume } \\
\text { fraction (Vol. \%) }\end{array}$ & $\begin{array}{l}\text { Actual volume } \\
\text { fraction (Vol. \%) }\end{array}$ \\
\hline \multirow{5}{*}{$\begin{array}{l}\text { Tool rotational } \\
\text { speed (rpm)* }\end{array}$} & 800 & 27 & 5 & 11.7 & 6.7 \\
\hline & 900 & 30 & 6 & 11.7 & 5.8 \\
\hline & 1000 & 33 & 8 & 11.7 & 5.3 \\
\hline & 1100 & 37 & 10 & 11.7 & 4.7 \\
\hline & 1200 & 43 & 13 & 11.7 & 4.1 \\
\hline \multirow{5}{*}{$\begin{array}{l}\text { Traverse speed } \\
(\mathrm{mm} / \mathrm{min})^{* *}\end{array}$} & 20 & 47 & 14.5 & 11.7 & 3.7 \\
\hline & 30 & 41 & 11 & 11.7 & 4.3 \\
\hline & 40 & 33 & 8 & 11.7 & 5.3 \\
\hline & 50 & 29 & 6.5 & 11.7 & 6.0 \\
\hline & 60 & 24 & 4 & 11.7 & 7.3 \\
\hline \multirow{5}{*}{$\begin{array}{l}\text { Groove width } \\
(\mathrm{mm})^{* * *}\end{array}$} & 0 & 44 & 13 & 0.0 & 0.0 \\
\hline & 0.35 & 37 & 11.5 & 5.8 & 2.4 \\
\hline & 0.7 & 33 & 8 & 11.7 & 5.8 \\
\hline & 1.05 & 27 & 5.5 & 17.5 & 9.7 \\
\hline & 1.4 & 24 & 2 & 23.3 & 14.6 \\
\hline
\end{tabular}

of $\mathrm{B}_{4} \mathrm{C}$ particles at several places. When tool rotational speed was increased, the agglomerations gradually disappeared. The optical micrograph of surface composite fabricated at $1200 \mathrm{rpm}$ shows (figure 7e) excellent distribution of $\mathrm{B}_{4} \mathrm{C}$ particles. The SEM micrographs as presented in figure 8 show the variation of microstructures as a function of tool rotational speed at higher magnification. The average spacing between $\mathrm{B}_{4} \mathrm{C}$ particles increased when tool rotational speed was increased. Tool rotational speed does two more functions apart from frictional heat generation. Tool rotation stirs the plasticized materials as well as influences material flow behaviour across the friction stir processed zone. The formation of agglomerations at $800 \mathrm{rpm}$ can be attributed to insufficient stirring and inadequate material flow from the advancing side to retreading side. The $\mathrm{B}_{4} \mathrm{C}$ particles which were packed in the groove did not mix with the plasticized copper properly. Hence, agglomerations were formed. When tool rotational speed increased, the amount of stirring and material flow are increased. The friction stir processing zone where surface composite is formed is subjected to high plastic strain. The high plastic strain and enhanced stirring shatter the agglomerations into fine dispersion in the copper matrix. The optical and SEM micrographs of the surface composite fabricated at $1200 \mathrm{rpm}$ show agglomeration-free fine distribution of $\mathrm{B}_{4} \mathrm{C}$ particles. It is evident from the micrographs that the tool rotational speed is an important process parameter which significantly dictates the distribution of $\mathrm{B}_{4} \mathrm{C}$ particles.

The effect of tool rotational speed on the microhardness of $\mathrm{Cu} / \mathrm{B}_{4} \mathrm{C}$ surface composite is shown in figure 9 . The microhardness decreased when tool rotational speed was increased. The microhardness was found to be $175 \mathrm{Hv}$ at $800 \mathrm{rpm}$ and $132 \mathrm{Hv}$ at $1200 \mathrm{rpm}$. The presence of agglomerations causes a higher variation of hardness across the surface composite. The possibility of indenter resting directly on the $\mathrm{B}_{4} \mathrm{C}$ particles increased due to agglomerations when hardness measurement was carried out at even spacing. This leads to higher hardness at $800 \mathrm{rpm}$. The decrease in hardness when tool rotational speed was increased can be attributed to the following. The increase in tool rotational speed breaks up agglomerations as discussed above. The 


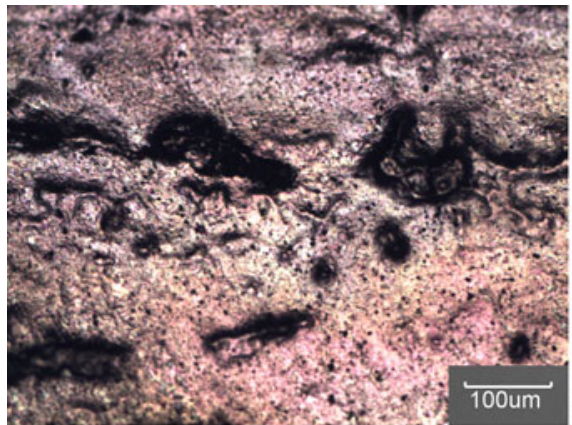

(a)

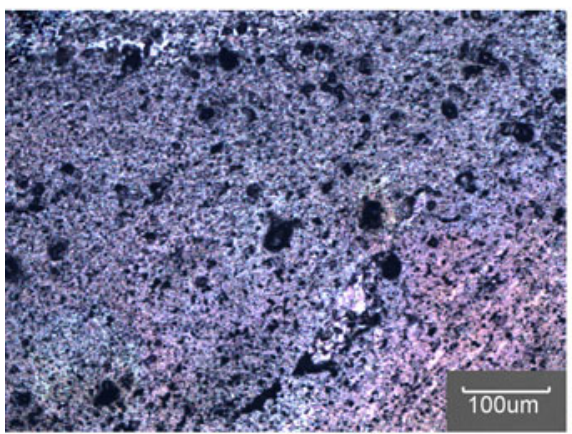

(c)

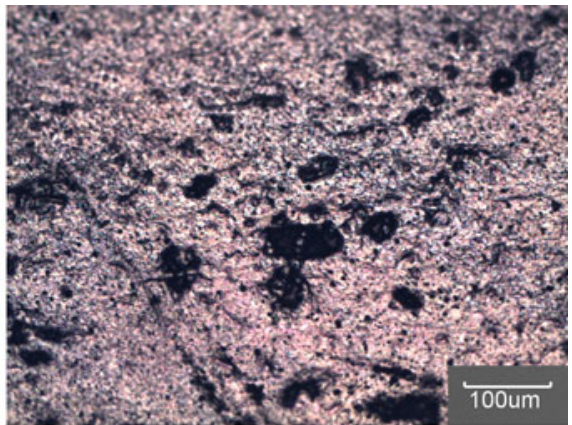

(b)

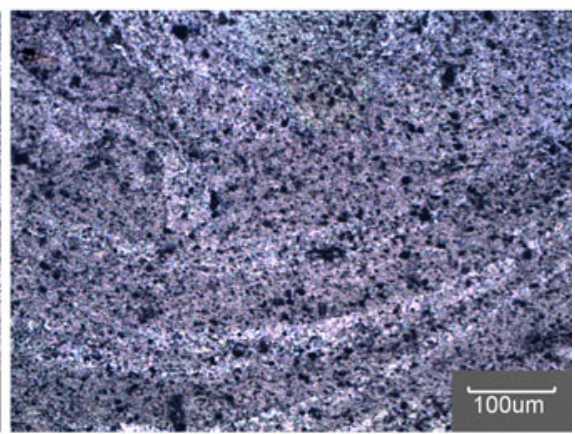

(d)

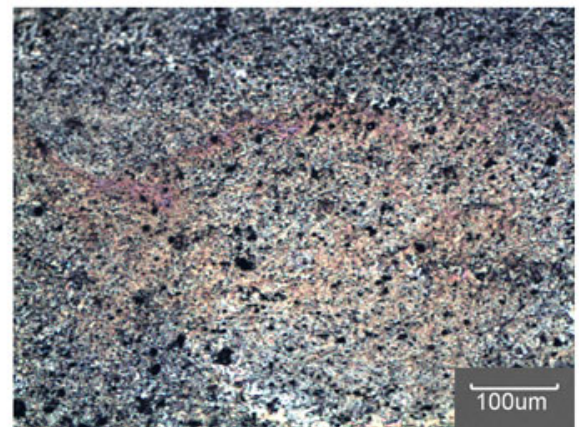

(e)

Figure 7. Optical photomicrograph of $\mathrm{Cu} / \mathrm{B}_{4} \mathrm{C}$ surface composite at tool rotational speed: (a) $800 \mathrm{rpm}$, (b) $900 \mathrm{rpm}$, (c) $1000 \mathrm{rpm}$, (d) $1100 \mathrm{rpm}$ and (e) $1200 \mathrm{rpm}$.

distribution of $\mathrm{B}_{4} \mathrm{C}$ particles becomes uniform at higher tool rotational speed. Since the area of surface composite concurrently increases, it results in an overall drop in volume fraction of $\mathrm{B}_{4} \mathrm{C}$ particles (table 2). Because, the same amount of $\mathrm{B}_{4} \mathrm{C}$ particles packed in the groove is to be distributed to more amount of plasticized copper. Therefore, the hardness of the surface composite is lower at $1200 \mathrm{rpm}$.

\subsection{Effect of processing speed}

The variation of macrostructure when processing speed was increased from $20 \mathrm{~mm} / \mathrm{min}$ to $60 \mathrm{~mm} / \mathrm{min}$ is presented in figure 10 . The tool rotational speed $(1000 \mathrm{rpm})$ and groove width 


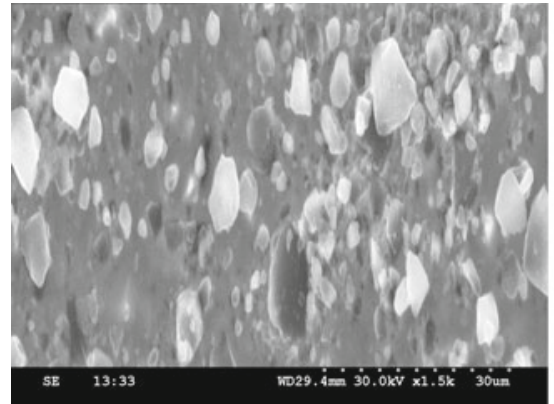

(a)

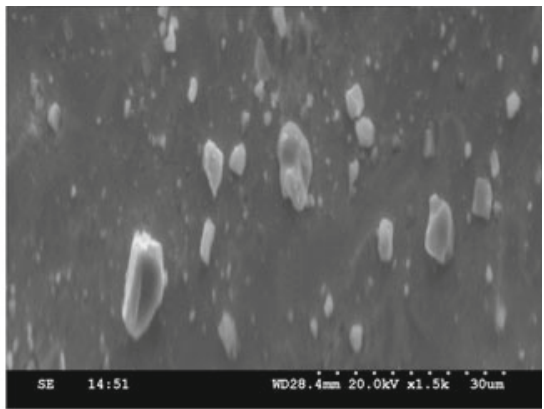

(b)

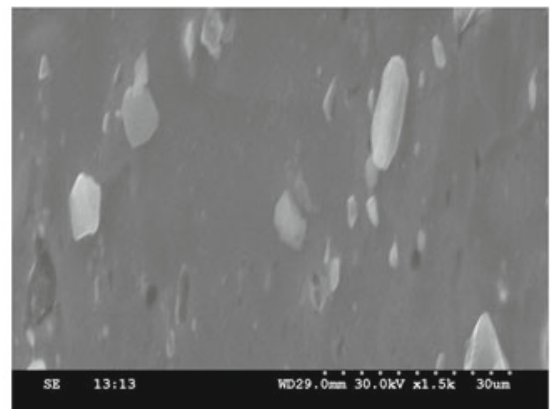

(c)

Figure 8. SEM micrograph of $\mathrm{Cu} / \mathrm{B}_{4} \mathrm{C}$ surface composite at tool rotational speed: (a) $800 \mathrm{rpm}$, (b) $1000 \mathrm{rpm}$ and (c) $1200 \mathrm{rpm}$.

$(0.7 \mathrm{~mm})$ were kept constant. It is evident from the figure and table 2 that the processing speed greatly influenced the area of surface composite. When processing speed was increased, the area of surface composite decreased. The area of the surface composite was found to be $45 \mathrm{~mm}^{2}$ at $20 \mathrm{~mm} / \mathrm{min}$ and $23 \mathrm{~mm}^{2}$ at $60 \mathrm{~mm} / \mathrm{min}$. The processing speed determines the residing time of the frictional heat (Mishra \& Ma 2005). When processing speed is increased, the residing time of the frictional heat is decreased. The residing time is high at low processing speed of $20 \mathrm{~mm} / \mathrm{min}$. Hence, more amount of copper is plasticized leading to higher area of surface composite. When processing speed is increased, the amount of plasticized copper is decreased due to reduced availability of frictional heat. The area of surface composite is subsequently reduced.

The effect of processing speed on the microstructure of $\mathrm{Cu} / \mathrm{B}_{4} \mathrm{C}$ surface composite is shown in figure 11. The optical micrograph of surface composite fabricated at $20 \mathrm{~mm} / \mathrm{min}$ shows (figure 11a) homogeneous distribution of $\mathrm{B}_{4} \mathrm{C}$ particles. The distribution is not uniform (figure 11e) at $60 \mathrm{~mm} / \mathrm{min}$ due to the presence of agglomeration of $\mathrm{B}_{4} \mathrm{C}$ particles at several places. When processing speed was increased, the agglomerations gradually increased. The SEM micrographs as presented in figure 12 show the variation of microstructures as a function of processing speed at higher magnification. The average spacing between $\mathrm{B}_{4} \mathrm{C}$ particles decreased when processing speed was increased. The processing speed determines the available stirring of tool and affects the transportation of material from advancing side to retreading side. The available stirring is more at processing speed of $20 \mathrm{~mm} / \mathrm{min}$ which results in higher plastic strain. The uniform distribution of $\mathrm{B}_{4} \mathrm{C}$ particles as seen in the micrographs (figures $11 \mathrm{a}-\mathrm{b}$ ) can be attributed to intense stirring and sufficient material flow which reduces the possibility of formation of 


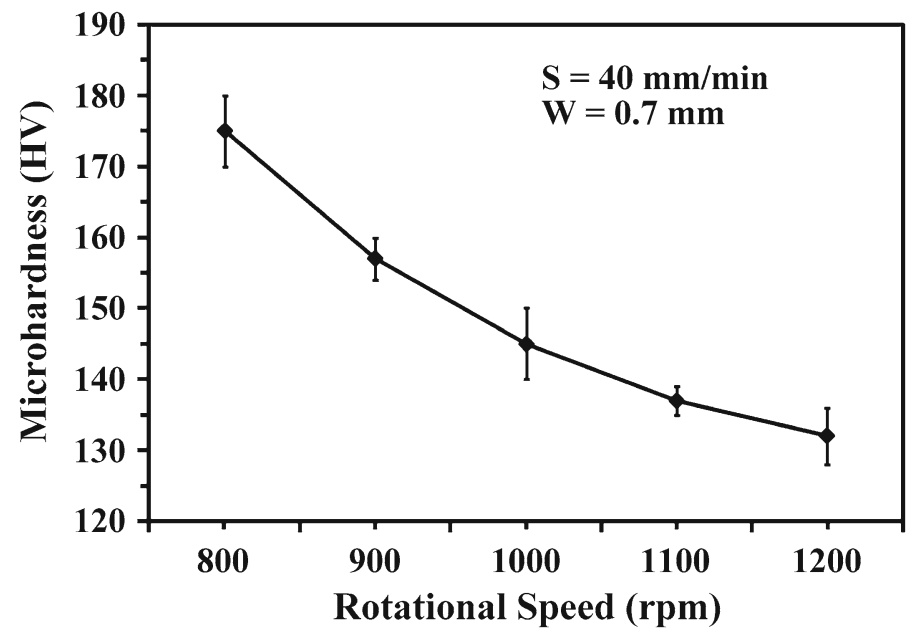

Figure 9. Effect of tool rotational speed on microhardness variation of $\mathrm{Cu} / \mathrm{B}_{4} \mathrm{C}$ surface composite.

agglomerations. When processing speed increases, the material flow between advancing side and retreading side becomes inadequate. Proper mixing of plasticized copper and $\mathrm{B}_{4} \mathrm{C}$ particles does not place which aids the formation of agglomerations.

The effect of processing speed on the microhardness of $\mathrm{Cu} / \mathrm{B}_{4} \mathrm{C}$ surface composite is shown in figure 13. The microhardness increased when processing speed was increased. The microhardness was found to be $130 \mathrm{Hv}$ at $20 \mathrm{~mm} / \mathrm{min}$ and $190 \mathrm{Hv}$ at $60 \mathrm{~mm} / \mathrm{min}$. The lower microhardness at $20 \mathrm{~mm} / \mathrm{min}$ can be attributed to drop in volume fraction of $\mathrm{B}_{4} \mathrm{C}$ particles despite uniform distribution. The formation of agglomerations results in higher microhardness when processing speed is increased.

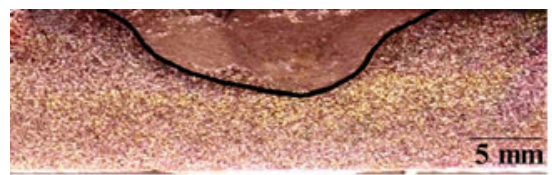

(a)

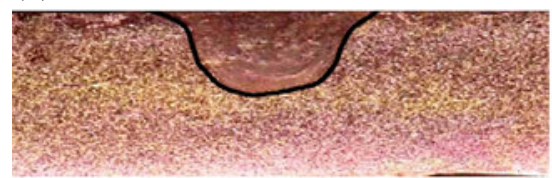

(c)

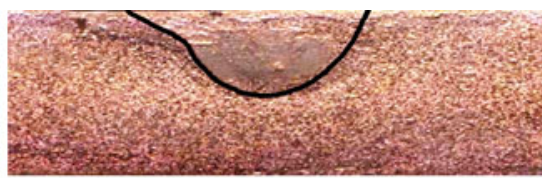

(b)

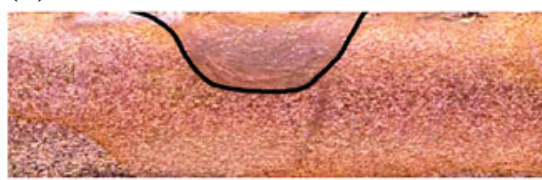

(d)

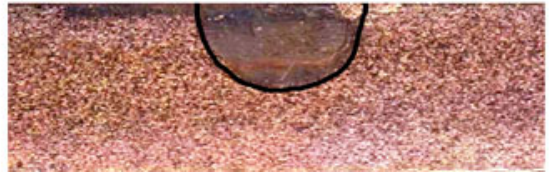

(e)

Figure 10. Macrostructure of friction stir zone at processing speed: (a) $20 \mathrm{~mm} / \mathrm{min}$, (b) $30 \mathrm{~mm} / \mathrm{min}$, (c) $40 \mathrm{~mm} / \mathrm{min}$, (d) $50 \mathrm{~mm} / \mathrm{min}$ and (e) $60 \mathrm{~mm} / \mathrm{min}$. 


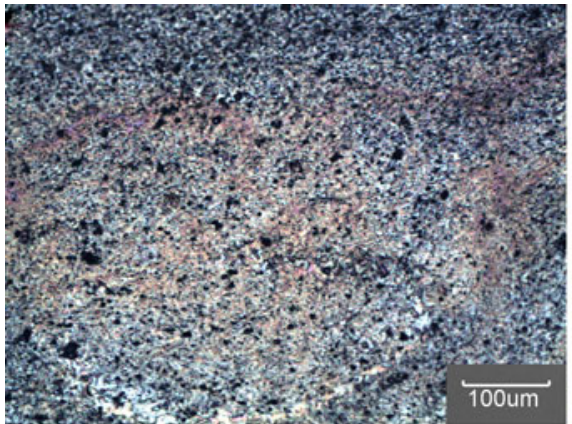

(a)

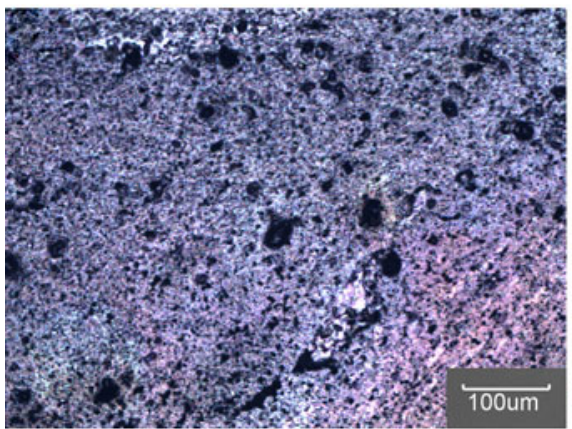

(c)

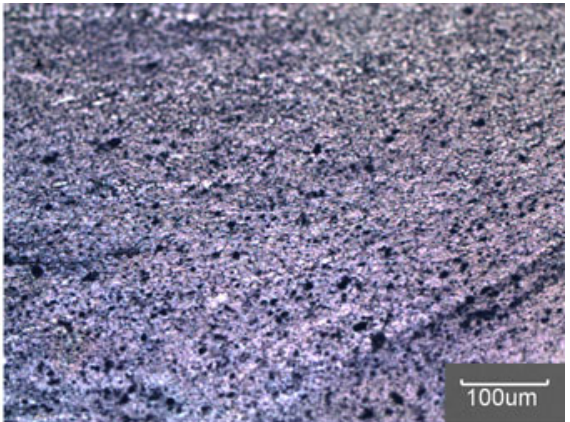

(b)

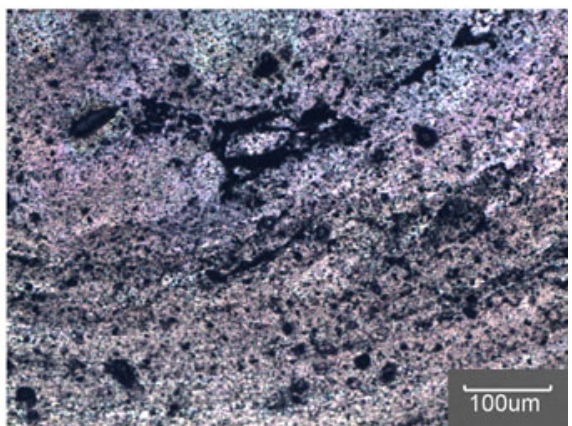

(d)

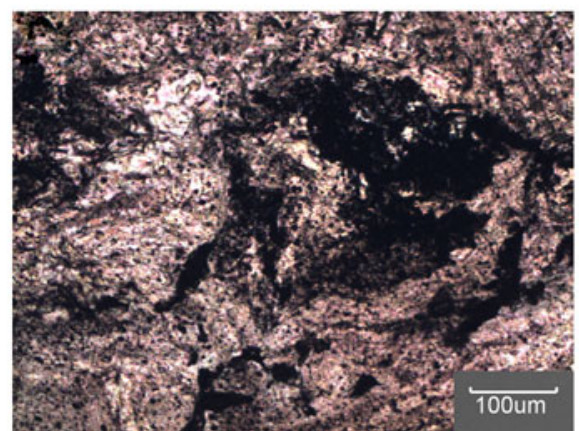

(e)

Figure 11. Optical photomicrograph of $\mathrm{Cu} / \mathrm{B}_{4} \mathrm{C}$ surface composite at processing speed: (a) $20 \mathrm{~mm} / \mathrm{min}$, (b) $30 \mathrm{~mm} / \mathrm{min}$, (c) $40 \mathrm{~mm} / \mathrm{min}$, (d) $50 \mathrm{~mm} / \mathrm{min}$ and (e) $60 \mathrm{~mm} / \mathrm{min}$.

\subsection{Effect of groove width}

The variation of macrostructure when groove width was increased from $0 \mathrm{~mm}$ to $1.4 \mathrm{~mm}$ is presented in figure 14 . The tool rotational speed $(1000 \mathrm{rpm})$ and processing speed $(40 \mathrm{~mm} / \mathrm{min})$ were kept constant. It is evident from the figure 14 and table 2 that the groove width influenced the area of surface composite to a certain extent. When the groove width was increased, the area of surface composite decreased. The area of the surface composite was found to be $44 \mathrm{~mm}^{2}$ at $0 \mathrm{~mm}$ and $24 \mathrm{~mm}^{2}$ at $1.4 \mathrm{~mm}$. The reduction in area of the surface composite can be explained as follows. The increase in groove width contributes to two factors: (i) increases the amount of $\mathrm{B}_{4} \mathrm{C}$ particles and (ii) reduces the amount of available copper for plasticization. When the 


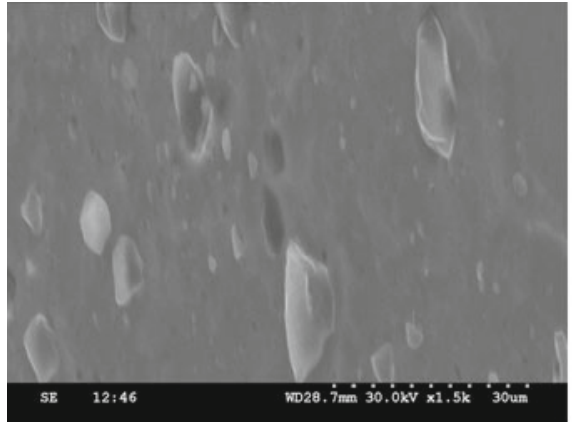

(a)

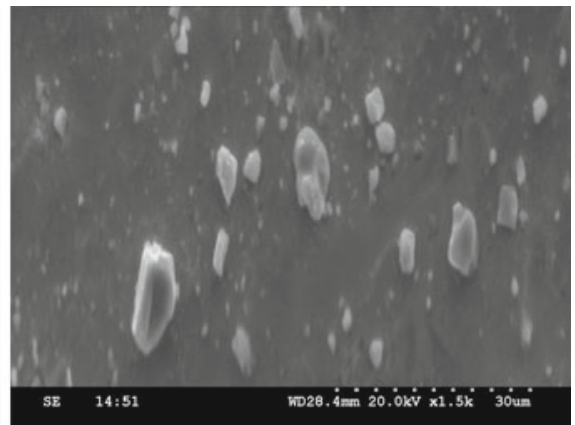

(b)

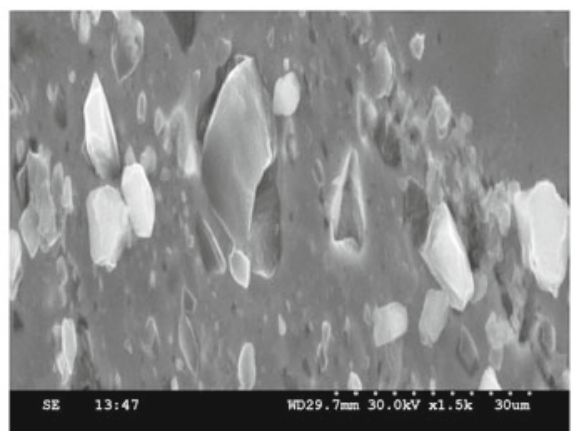

(c)

Figure 12. SEM microgaph of $\mathrm{Cu} / \mathrm{B}_{4} \mathrm{C}$ surface composite at processing speed: (a) $20 \mathrm{~mm} / \mathrm{min}$, (b) $40 \mathrm{~mm} / \mathrm{min}$ and (c) $60 \mathrm{~mm} / \mathrm{min}$.

amount of $\mathrm{B}_{4} \mathrm{C}$ particles increases, it leads to increase in flow stress of the plasticized composite. Because the non-deformable $\mathrm{B}_{4} \mathrm{C}$ particles offer resistance to the free flow of plasticized copper. In addition to this, the reduction in available copper boosts the volume fraction of $\mathrm{B}_{4} \mathrm{C}$ particles nonlinearly in the surface composite. The net result is a higher flow stress of the surface composite. Therefore, the area of the surface composite reduces when groove width is increased.

The effect of groove width on the microstructure of $\mathrm{Cu} / \mathrm{B}_{4} \mathrm{C}$ surface composite is shown in figure 15. Groove width zero refers to friction stir processed copper. The optical micrograph of friction stir processed copper is shown in figure 15a which displays dynamic recrystallized copper. The optical micrographs as shown in figures $15 \mathrm{~b}-\mathrm{e}$ show the uniform distribution of $\mathrm{B}_{4} \mathrm{C}$ particles irrespective of groove width studied in this work. The SEM micrographs as presented in figure 16 show the variation of microstructures as a function of groove width at higher magnification. The number of particles increase as well as the spacing between particles reduces when groove width is increased. The uniform distribution of $\mathrm{B}_{4} \mathrm{C}$ particles can be attributed to adequate generation of frictional heat, stirring and plasticized material flow across the friction stir processed zone. Mild agglomerations were also observed at few locations. The volume fraction of $\mathrm{B}_{4} \mathrm{C}$ particles increases when groove width is increased. Subsequently the number of $\mathrm{B}_{4} \mathrm{C}$ particles increases and the spacing between particles decreases.

The effect of groove width on the microhardness of $\mathrm{Cu} / \mathrm{B}_{4} \mathrm{C}$ surface composite is shown in figure 17. The microhardness increased when groove width was increased. The microhardness was found to be $80 \mathrm{Hv}$ at $0 \mathrm{~mm}$ and $195 \mathrm{Hv}$ at $1.4 \mathrm{~mm}$. The reinforcement of $\mathrm{B}_{4} \mathrm{C}$ particles increases the dislocation density of copper. The interaction between $\mathrm{B}_{4} \mathrm{C}$ particles and 


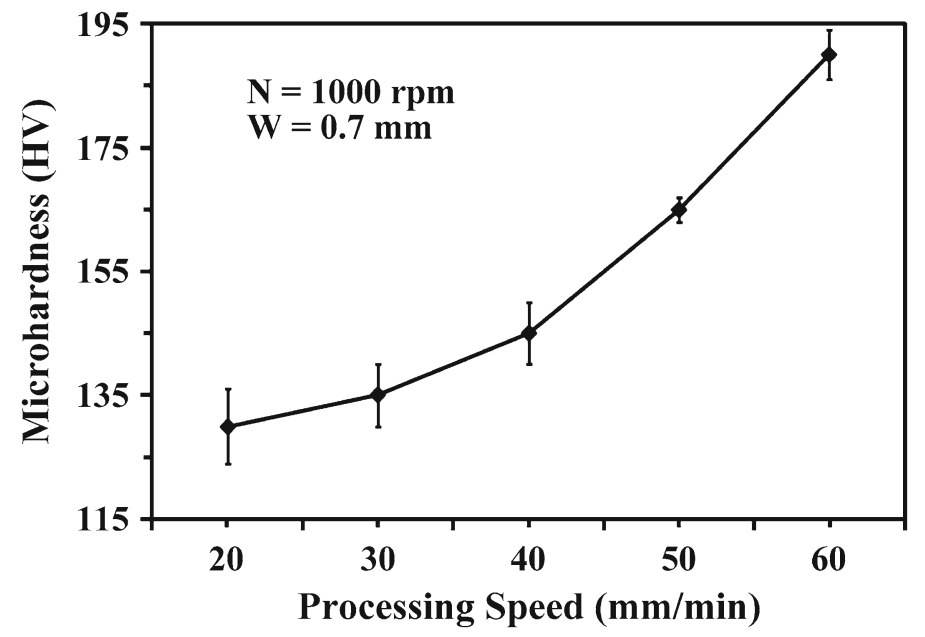

Figure 13. Effect of processing speed on microhardness variation of $\mathrm{Cu} / \mathrm{B}_{4} \mathrm{C}$ surface composite.

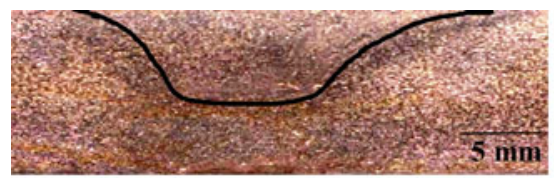

(a)

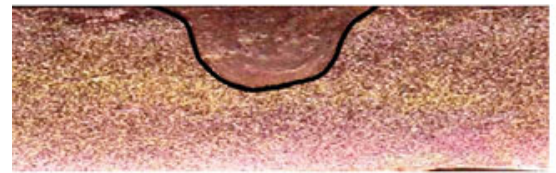

(c)

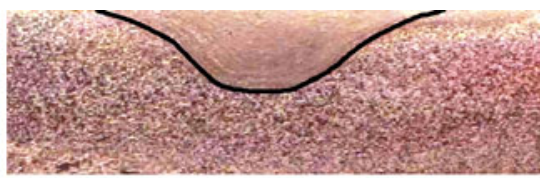

(b)

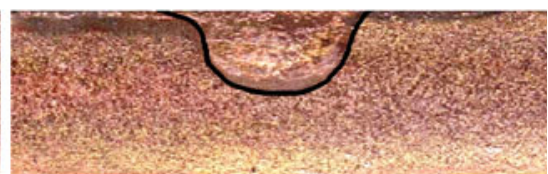

(d)

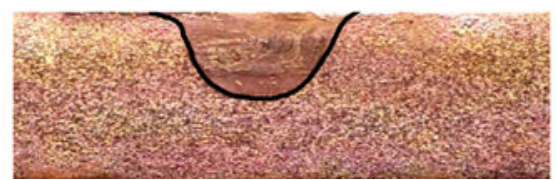

(e)

Figure 14. Macrostructure of friction stir zone at groove width: (a) $0 \mathrm{~mm}$, (b) $0.35 \mathrm{~mm}$, (c) $0.70 \mathrm{~mm}$, (d) $1.05 \mathrm{~mm}$ and (e) $1.4 \mathrm{~mm}$.

dislocations increases the microhardness of the composite. Hence, microhardness increases when groove width is increased from $0 \mathrm{~mm}$ to $0.35 \mathrm{~mm}$. As presented in table 2, the volume fraction of $\mathrm{B}_{4} \mathrm{C}$ particles increases when the groove width is increased. This leads to more number of dislocations in the copper. This results in higher interactions between $\mathrm{B}_{4} \mathrm{C}$ particles and dislocations which further increases microhardness.

\subsection{General discussion}

The general features observed in figures 6-17 are discussed in this section. The macrostructure of $\mathrm{Cu} / \mathrm{B}_{4} \mathrm{C}$ surface composites does not have any defects as shown in figures 6,10 and 14 . The 


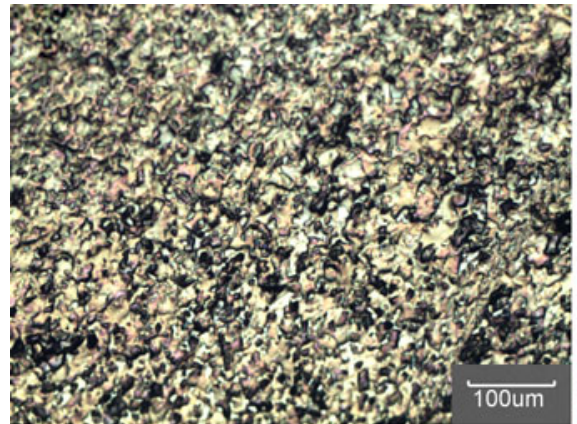

(a)

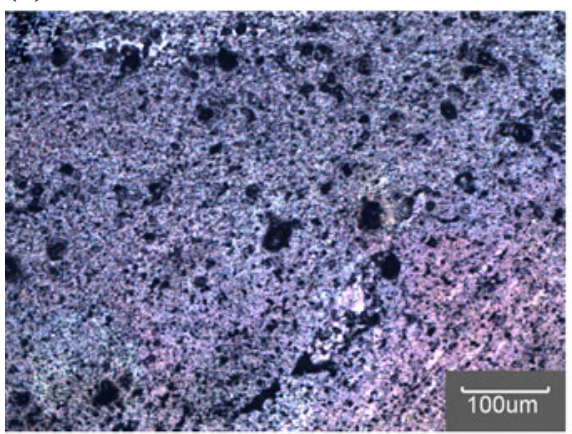

(c)

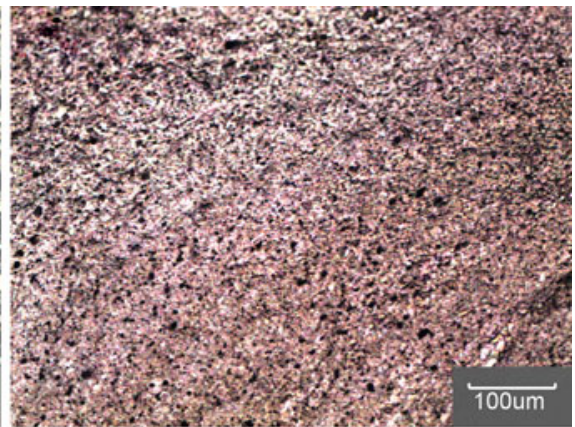

(b)

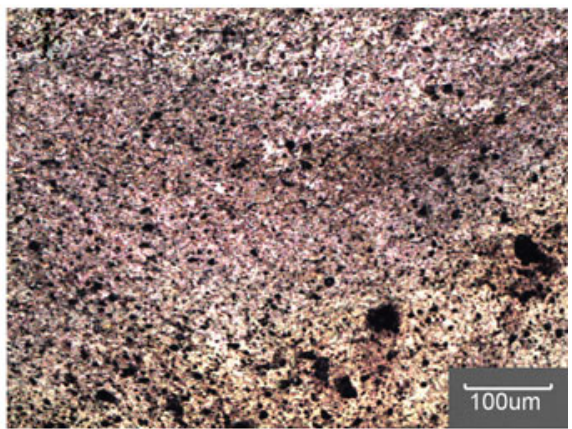

(d)

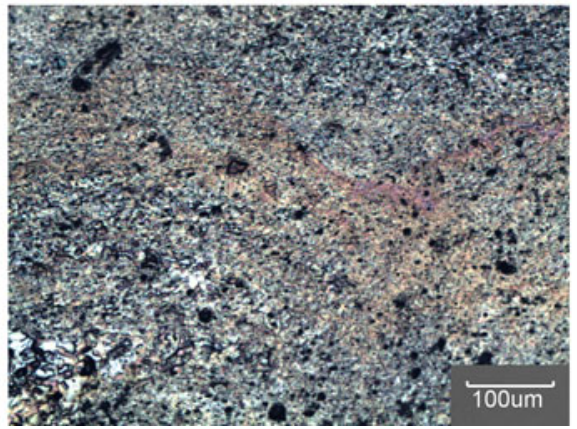

(e)

Figure 15. Optical photomicrograph of $\mathrm{Cu} / \mathrm{B}_{4} \mathrm{C}$ surface composite at groove width: (a) $0 \mathrm{~mm}$, (b) $0.35 \mathrm{~mm}$, (c) $0.70 \mathrm{~mm}$, (d) $1.05 \mathrm{~mm}$ and (e) $1.4 \mathrm{~mm}$.

vigorous stirring action of the rotating tool causes an interaction between the plasticized copper and packed $\mathrm{B}_{4} \mathrm{C}$ particles which results in the formation of surface composite. The amount of plasticized material and subsequent material flow behaviour play a crucial role to obtain defect free surface composite. The frictional heat generated during processing and the tool movement governs the amount of plasticized material and material flow. The frictional heat and tool movement are dependent on the process parameters such as tool rotational speed, processing speed and groove width. The selected process parameters in this study form a feasible processing window to fabricate sound $\mathrm{Cu} / \mathrm{B}_{4} \mathrm{C}$ surface composites.

It is evident from table 2 that the actual volume fraction of $\mathrm{B}_{4} \mathrm{C}$ particles is lesser compared to theoretical volume fraction irrespective of the process parameters employed in this study. This 


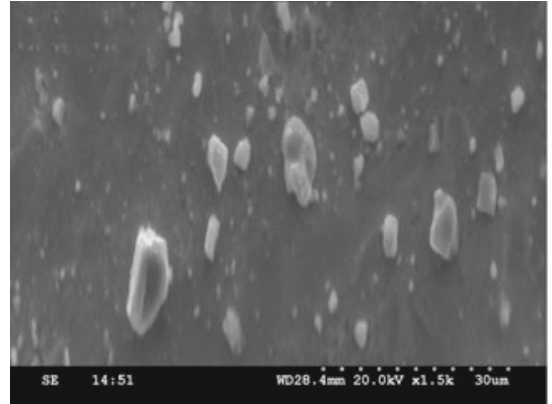

(a)

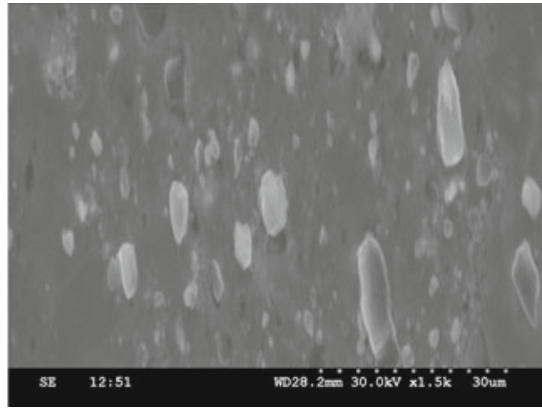

(b)

Figure 16. SEM micrograph of $\mathrm{Cu} / \mathrm{B}_{4} \mathrm{C}$ surface composite at groove width: (a) $0.70 \mathrm{~mm}$ and (e) $1.4 \mathrm{~mm}$.

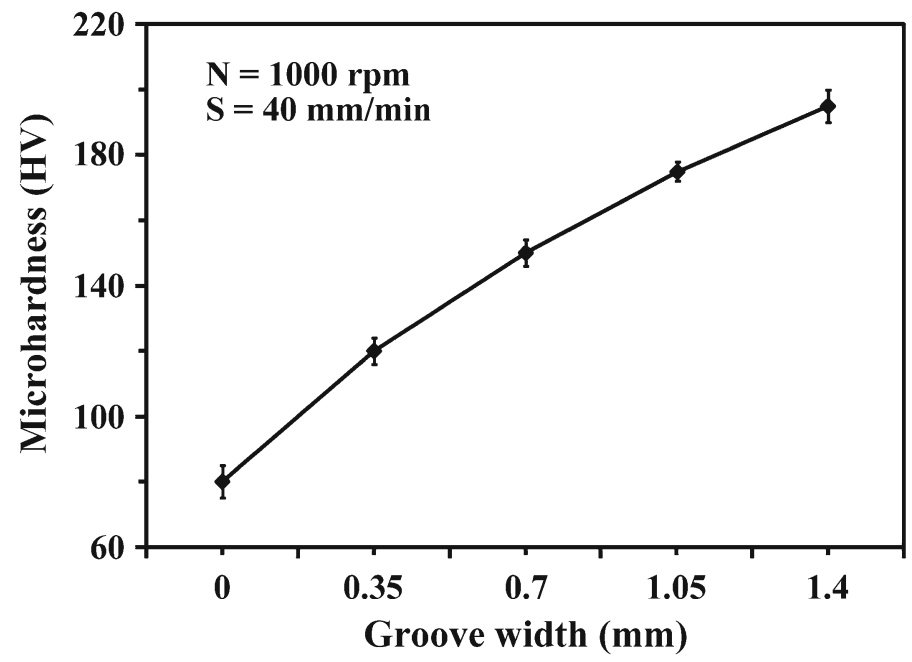

Figure 17. Effect of groove width on microhardness variation of $\mathrm{Cu} / \mathrm{B}_{4} \mathrm{C}$ surface composite.

can be attributed to higher amount of plasticized copper at the selected FSP parameters compared to theoretically available copper.

The $\mathrm{B}_{4} \mathrm{C}$ particles refined the grains of copper. The average grain size of copper as shown in figure 2 is about $30-35 \mu \mathrm{m}$ measured using a linear intercept method. The average grain size of copper in the surface composite is less than $5 \mu \mathrm{m}$. The grain refinement can be attributed to the pinning effect of $\mathrm{B}_{4} \mathrm{C}$ particles which impede the grain growth by suppressing grain boundary sliding. Further, dynamic recrystallization during FSP creates new nucleation sites which results in smaller grains.

The $\mathrm{B}_{4} \mathrm{C}$ particles are subjected to the severe plastic flow of copper. Several investigators observed a change in the size and morphology of ceramic particles during FSW (Marzoli et al 2006; Amirizad et al 2006; Ceschini et al 2007; Feng et al 2008; Pirondi and Collini 2009). The variation of $\mathrm{B}_{4} \mathrm{C}$ particles size in the surface composite as seen in figures 8,12 and 16 is minimum and negligible. The variation in the morphology of the $\mathrm{B}_{4} \mathrm{C}$ particles before (figure 1) and after (figures 8, 12 and 16) FSP is negligible. These observations lead to a conclusion that the 
$\mathrm{B}_{4} \mathrm{C}$ particles retain the initial size and morphology without undergoing fragmentation during FSP. This can be attributed to the initial morphology and size of $\mathrm{B}_{4} \mathrm{C}$ particles which have a minimum number of sharp edges and less than $5 \mu \mathrm{m}$ in size.

The interface between $\mathrm{B}_{4} \mathrm{C}$ particles and copper matrix appears (figures 8, 12 and 16) to be clean and is not surrounded by any voids or reaction products. Barmouz et al (2011b) observed a lot of porosities around $\mathrm{SiC}$ particles in the $\mathrm{Cu} / \mathrm{SiC}$ surface composite fabricated using FSP technique. Frage et al (2004) noticed reaction products around $\mathrm{SiC}$ particles in the $\mathrm{Cu} / \mathrm{SiC}$ composite fabricated using the liquid metallurgy route. No porosity or reaction products can be seen in the higher magnification micrographs of the $\mathrm{Cu} / \mathrm{B}_{4} \mathrm{C}$ surface composite around $\mathrm{B}_{4} \mathrm{C}$ particles which confirms the presence of pure interface. The absence of porosity can be attributed to good wettability between copper and $\mathrm{B}_{4} \mathrm{C}$ particles and sufficient flow of plasticized copper during FSP at the selected process parameters. A pure interface provides good bonding between $\mathrm{B}_{4} \mathrm{C}$ particles and copper matrix.

The microhardness of as received copper was measured to be $78.8 \mathrm{Hv}$. It is evident from figures 9, 13 and 17 that the incorporation of $\mathrm{B}_{4} \mathrm{C}$ particles enhanced the microhardness of the fabricated surface composite which can be attributed to the following; (i) $\mathrm{B}_{4} \mathrm{C}$ particles refine the crystal grains of copper, (ii) the dispersion of $\mathrm{B}_{4} \mathrm{C}$ particles all over the $\mathrm{Cu}$ matrix and (iii) good bonding between $\mathrm{B}_{4} \mathrm{C}$ particles and copper matrix.

\section{Conclusion}

In the present work, $\mathrm{Cu} / \mathrm{B}_{4} \mathrm{C}$ surface composites were fabricated using the novel method FSP and the effect of tool rotational speed, processing speed and groove width on microstructure and microhardness were analysed. The conclusion derived from the present work can be summarized as follows:

- Defect-free and sound surface composites were fabricated within the range of selected parameters which formed a processing window for fabricating $\mathrm{Cu} / \mathrm{B}_{4} \mathrm{C}$ surface composites using FSP. The frictional heat generated and flow of plasticized copper was adequate which yielded defect free composites.

- The area of the surface composite was significantly influenced by the selected process parameters. The area of the surface composite increased when tool rotational speed was increased due to increase in frictional heat generation. The area of the surface composite reduced when processing speed was increased because of reduction in frictional heat generation. The area of the surface composite reduced when groove width was increased due to increase in flow stress of plastized copper.

- The distribution of $\mathrm{B}_{4} \mathrm{C}$ particles in the surface composites was influenced by tool rotational speed and processing speed. Lower tool rotational speed and higher processing speed resulted in poor distribution of $\mathrm{B}_{4} \mathrm{C}$ particles and vice versa. The increase in groove width did not affect the distribution of $\mathrm{B}_{4} \mathrm{C}$ particles in a significant manner.

- The $\mathrm{B}_{4} \mathrm{C}$ particles refined the grains of copper because of its pinning effect. The interface between $\mathrm{B}_{4} \mathrm{C}$ particles and copper matrix was clean without the presence of any voids or reaction products. The absence of porosity can be attributed to good wettability between copper and $\mathrm{B}_{4} \mathrm{C}$ particles and sufficient flow of plasticized copper during FSP at the selected process parameters.

- The $\mathrm{B}_{4} \mathrm{C}$ particles retained the original size and morphology subsequent to FSP. Because, the initial morphology $\mathrm{B}_{4} \mathrm{C}$ particles had minimum number of sharp edges and finer in size. 
- The microhardness of the surface composites was influenced by the selected process parameters. The microhardness of the surface composite decreased when tool rotational speed was increased. The microhardness of the surface composite increased when processing speed and groove width were increased. The microhardness variation was attributed to the change in the distribution and actual volume fraction of $\mathrm{B}_{4} \mathrm{C}$ particles.

\section{Acknowledgements}

The authors are thankful to the Management and Department of Mechanical Engineering, Coimbatore Institute of Technology, Coimbatore, India for extending the facilities to carry out this investigation. The authors also acknowledge the financial support rendered by the Naval Research Board, Defence Research and Development Organization (DRDO), Government of India. One of the authors, Dr. I. Dinaharan thanks the Department of Science and Technology (DST), Govt. of India for providing INSPIRE fellowship. The authors are also thankful to Mr. K Kalaiselvan, Mr. C Maxwell Rejil, Mr. G Ashok Kumar for their assistance.

\section{References}

Amirizad M, Kokabi A H, Gharacheh M A, Sarrafi R, Shalchi B and Azizieh M 2006 Evaluation of microstructure and mechanical properties in friction stir welded $\mathrm{A} 356+15 \% \mathrm{SiC}_{\mathrm{p}}$ cast composite. Mater. Lett. 60: 565-568

Asadi P, Faraji G and Besharati M K 2010 Producing of AZ91/SiC composite by friction stir processing (FSP). Int. J. Adv. Manuf. Technol. 51: 247-260

Asadi P, Givi M K B, Abrinia K, Taherishargh M and Salekrostam R 2011 Effects of SiC Particle Size and Process Parameters on the Microstructure and Hardness of AZ91/SiC Composite Layer Fabricated by FSP. J. Mater. Eng. Perform. 20: 1554-1562

Attia A N 2001 Surface metal matrix composites. Mater. Des. 22: 451-457

Azizieh M, Kokabi A H and Abachi P 2011 Effect of rotational speed and probe profile on microstructure and hardness of $\mathrm{AZ} 31 / \mathrm{Al}_{2} \mathrm{O}_{3}$ nanocomposites fabricated by friction stir processing. Mater. Des. 32: 2034-2041

Barmouz M and Givi M K B 2011 Fabrication of in situ Cu/SiC composites using multi-pass friction stir processing: Evaluation of microstructural, porosity, mechanical and electrical behavior. Compos. Part A 42: $1445-1453$

Barmouz M, Givi M K B and Seyfi J 2011a On the role of processing parameters in producing $\mathrm{Cu} / \mathrm{SiC}$ metal matrix composites via friction stir processing: Investigating microstructure, microhardness, wear and tensile behavior. Mater. Charact. 62: 108-117

Barmouz M, Asadi P, Givi M K B and Taherishargh M 2011b Investigation of mechanical properties of $\mathrm{Cu} / \mathrm{SiC}$ composite fabricated by FSP: Effect of SiC particles size and volume fraction. Mater. Sci. Eng. A 528: 1740-1749

Barmouz M, Givi M K B and Jafari J 2011c Influence of tool pin profile on the microstructure and mechanical behavior of $\mathrm{Cu} / \mathrm{SiC}$ metal matrix composites produced by friction stir processing. Adv. Mater. Res. 154-155: 1761-1766

Ceschini L, Boromei I, Minak G, Morri A, Tarterini F 2007 Effect of friction stir welding on microstructure, tensile and fatigue properties of the AA7005/10 vol. $\% \mathrm{Al}_{2} \mathrm{O}_{3 p}$ composite. Compos. Sci. Technol. 67: 605-615

Chen X G, Silva M, Gougeon P and St-Georges L 2009 Microstructure and mechanical properties of friction stir welded AA6063-B 4 C metal matrix composites. Mater. Sci. Eng. A 518: 174-184

Dhokey N B and Paretkar R K 2008 Study of wear mechanisms in copper-based $\mathrm{SiC}_{\mathrm{p}}$ (20\% by volume) reinforced composite. Wear 265: 117-133 
Feng A H, Xiao B L and Ma Z Y 2008 Effect of microstructural evolution on mechanical properties of friction stir welded AA2009/ $\mathrm{SiC}_{\mathrm{p}}$ composite. Compos. Sci. Technol. 68: 2141-2148

Frage N, Froumin N, Aizenshtein M and Dariel M P 2004 Interface reaction in the $\mathrm{B}_{4} \mathrm{C} /(\mathrm{Cu}-\mathrm{Si})$ system. Acta. Mater. 52: 2625-2635

Guo J, Amira S, Gougeon P and Chen X G 2011 Effect of the surface preparation techniques on the EBSD analysis of a friction stir welded AA1100-B ${ }_{4}$ C metal matrix composite. Mater. Charact. 62: 865-877

Guo J, Gougeon P and Chen X G 2012 Characterisation of welded joints produced by FSW in AA1100-B 4 C metal matrix composites. Sci. Technol. Weld. Joining 17: 85-91

Mahmoud E R I, Ikeuchi K and Takahashi M 2008 Fabrication of SiC particle reinforced composite on aluminium surface by friction stir processing. Sci. Technol. Weld. Joining 13: 607-618

Mahmoud E R I, Takahashi M, Shibayanagi T and Ikeuchi K 2009 Effect of friction stir processing tool probe on fabrication of $\mathrm{SiC}$ particle reinforced composite on aluminium surface. Sci. Technol. Weld. Joining 14: 413-425

Maruyama T and Onose S 1999 Fabrication and thermal conductivity of boron carbide/copper cermet. J. Nucl. Sci. Technol. 36: 380-385

Marzoli L M, Strombeck A V, Santos J F, Gambaro C and Volpone L M 2006 Friction stir welding of an AA6061/ $\mathrm{Al}_{2} \mathrm{O}_{3} / 20$ p reinforced alloy. Compos. Sci. Technol. 66: 363-371

Mazaheri Y, Karimzadeh F and Enayati M H 2011 A novel technique for development of $\mathrm{A} 356 / \mathrm{Al}_{2} \mathrm{O}_{3}$ surface nanocomposite by friction stir processing. J. Mater. Process. Technol. 211: 1614-1619

Mishra R S and Ma Z Y 2005 Friction stir welding and processing. Mater. Sci. Eng. R 50: 1-78

Mishra R S, Ma Z Y and Charit I 2003 Friction stir processing: a novel technique for fabrication of surface composite. Mater. Sci. Eng. A 341: 307-310

Nanobashvili S, Matejıcek J, Zacek F, Stockel J, Chraska P and Brozek V 2002 Plasma sprayed coatings for RF wave absorption. J. Nucl. Mater. 307-311: 1334-1338

Pirondi A and Collini L 2009 Analysis of crack propagation resistance of $\mathrm{Al}-\mathrm{Al}_{2} \mathrm{O}_{3}$ particulate-reinforced composite friction stir welded butt joints. Int. J. Fatigue 31: 111-121

Rajakumar S, Muralidharan C and Balasubramanian V 2011 Influence of friction stir welding process and tool parameters on strength properties of AA7075-T6 aluminium alloy joints. Mater. Des. 32: 535-549

Salekrostam R, Givi M K B, Asadi P and Bahemmat P 2010 Influence of friction stir processing parameters on the fabrication of SiC/316L surface composite. Defect Diffus. Forum 297-301: 221-226

Shamsipura A, Bozorg S F K and Hanzakia A Z 2011 The effects of friction-stir process parameters on the fabrication of Ti/SiC nano-composite surface layer. Surf. Coat. Technol. 206: 1372-1381

Yadav D and Bauri R 2010 Nickel particle embedded aluminium matrix composite with high ductility. Mater. Lett. 64: 664-667

Yang M, Xu C, Wu C, Lin K C, Chao Y J and An L 2010 Fabrication of AA6061/ $\mathrm{Al}_{2} \mathrm{O}_{3}$ nano ceramic particle reinforced composite coating by using friction stir processing. J. Mater. Sci. 45: 4431-4438 